\title{
Introduktion til Tony Mangan
}

\author{
af Hans Bonde
}

Forfatteren til den efterfølgende artikel er en central skikkelse i britisk idrætsforskning. Mangan var oprindelig antropolog, men skiftede siden over til historisk forskning i skriftlige kilder. Mangans dynamik viser sig både ved hans evne til at få andres forskning udgivet og $\mathrm{i}$ hans egen store produktion. Han er i bedste forstand en igangsættertype. Som redaktør af Manchester University Press' serie »International Studies in the Social History of Sport « har han fået udgivet mange andre forskeres værker om britisk sportshistorie.

Mangan var hovedmand bag skabelsen af »The British Journal of Sports History«, som i maj 1984 udsendte sit første nummer med flere artikler om sportshistoriens og -sociologiens historiografi. Senere ændredes tidsskriftets titel til det mere ambitiøse »The International Journal of the History of Sport«, som søger at levere artikler især fra Common Wealth landene, men også fra resten af verden, således også Skandinavien og Danmark. Titelændringen fra "Sports History« til »The History of Sport« er ikke tilfældig, men reflekterer hos Mangan en afstandtagen fra den type sportshistorie, som for ham er overdrevent kronologisk bundet og teoretisk fattig. Mangans egen forskning er da også et forsøg på at sætte sporten ind i bredere socialhistoriske rammer. Faktisk hævder han ikke at være interesseret $i$ sportshistorie i sig selv, men udeluk- kende som et centralt udtryk for brede samfundsmæssige tendenser.

I et af hans hovedværker »Athleticism in the Victorian and Edwardian Public School« fra 1986 (Cambridge University Press) viste Mangan, at sporten havde en helt central placering på den engelske overklasses kostskoler i anden halvdel af 1800-tallets England. En dreng kunne trods mangelfulde boglige talenter klare sig igennem, hvis han var en god sportsmand. Sporten blev anset for at være et meget velegnet opdragelsesmiddel, og målet var at udvikle en »Muscular Christianity« i de unge mænd, dvs. en meget stoisk og fysisk form for kristendom med en aura af sved, vabler og buksevand. Mangans antropologiske baggrund fornægter sig ikke i et interessant afsnit om symboler og riter i disse Public Schools. Mangan mener, at sange, emblemer mv., var vigtige for skabelsen af en fællesidentitet og en identifikation med skolen.

I et andet centralt værk »The Games Ethic and Imperialism « fra 1985 (Penguin/Viking) følger Mangan den engelske sportslige kolonisering af store dele af verden, som fulgte i kølvandet på den militære og økonomiske imperialisme. Det er ikke mindst den nærmest messianske britiske ideologi, som har Mangans interesse, når han viser, hvorledes sportslige idealer om karakter og stoicisme indpodedes i aristokratiske kredse i de »uciviliserede « folkeslag, f.eks. i Indien. Udover Indien ta- 
ges også Afrika og Canada op til behandling. I flere antologier har Tony Mangan siden samlet forskellige forskeres studier i britisk »sportsimperialisme«. F.eks. i antologien »Pleasure, Profit and Proselytism « fra 1987 (Cass), og i antologien Sport in Africa« (Holmes \& Meyer) også fra 1987 (samredigeret med W. J. Baker). Den artikel som efterfølgende præsenteres, er et godt eksempel på Mangans interesse i den internationale udbredelse af den britiske sportsideologi.

Et tredje centralt felt i britisk sportsforskning (foruden kostskole- og impe-

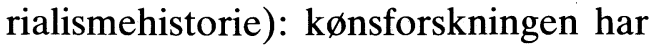
Mangan også været med til at fremme. Her skal nævnes antologierne »From
Fair Sex to Feminism《 fra 1987 (samred. med Roberta J. Park, Cass) og Manliness and Morality fra samme år (samred. med James Walvin, Manchester University Press).

Forvirres man af, at der ofte optræder en vis J. A. Mangan i britisk sportshistorie, skal man ikke lade sig narre. Dette er Mangans forfatternavn, men ellers omtales han som Tony. Sidste forår gav Mangan en forelæsning på Københavns Universitet, og han kan muligvis snart opleves på dansk grund igen. I så fald vil der da være mulighed for at opleve en spændende forsker, som kan kunsten at holde et publikum $i$ ånde. 